\title{
CREATIVE AND INNOVATIVE: AN ASSAY OF WORKERS
}

\author{
Creativo e innovador: Caracterizando a los Trabajadores
}

Criativos e inovadores: Caracterização dos trabalhadores

Sara Ibérico Nogueira - Universidade Lusófona de Humanidades e Tecnologias

Leonor S. Almeida - ISG Business \& Economics School

Tiago Jessé Souza Lima - University of Fortaleza

\author{
Sara Ibérico Nogueira \\ Universidade Lusófona de Humanidades e Tecnologias \\ saraiberico@hotmail.com \\ +351917802533 \\ Leonor S. Almeida \\ ISG-Business \& Economics School, Lisboa \\ leonorsalmeida@gmail.com \\ Tiago Jessé Souza Lima \\ University of Fortaleza / Federal University of Ceará \\ tiago.souzalima@hotmail.com
}




\begin{abstract}
A contemporary approach to creativity research emphasizes the fact that all people, in their work context, can contribute with creative ideas in some domain. In this sense, the organizational context has a determining influence (Amabile, 1996). The objective of this study is to analyse the impact of organization type (private- versus public-sector), education level, gender and age on creativity and perceived innovativeness with a sample of 611 Portuguese workers. These variables were operationalized by the Test for Creative ThinkingDrawing Production (TCT-DP) and the Innovativeness Inventory (II). Organization type and education level seem to be the best predictors for creativity and innovativeness, respectively. In the future, it intends to undertake a detailed characterization of the variables involved in the organizational climate as these may explain the lower creativity levels of public workers to some extent.
\end{abstract}

Keywords: creativity, innovativeness, organizations

\title{
Resumen
}

Un enfoque contemporáneo de la investigación en creatividad enfatiza el hecho de que todas las personas, en su contexto de trabajo, pueden contribuir con ideas creativas en algún ámbito. En este sentido, el contexto organizacional tiene una influencia determinante. El objetivo de este estudio es analizar el impacto del tipo de organización (sector privado versus público), nivel de educación, género y edad en la creatividad y la innovación percibida con una muestra de 611 trabajadores portugueses. Estas variables fueron operacionalizadas por el Test for Creative Thinking-Drawing Production (TCT-DP) y el Innovativeness Inventory (II). El tipo de organización y el nivel de educación parecen ser los mejores predictores de creatividad e innovación, respectivamente. En el futuro se pretende realizar una caracterización detallada 
de las variables involucradas en el clima organizacional, que pueden explicar hasta cierto punto el menor nivel de creatividad de los trabajadores públicos.

Palabras clave: creatividad; innovación; organizaciones

\section{Resumo}

Uma abordagem contemporânea à investigação sobre a criatividade enfatiza o facto de todas as pessoas, no seu contexto de trabalho, poderem contribuir com ideias criativas em algum domínio. Nesse sentido, o contexto organizacional tem uma influência determinante. O objetivo deste estudo é analisar o impacto do tipo de organização (setor privado versus público), nível de escolaridade, género e idade, na criatividade e inovação percebida, numa amostra de 611 trabalhadores portugueses. Estas variáveis foram operacionalizadas pelo Test for Creative Thinking-Drawing Production (TCT-DP) e pelo Innovativeness Inventory (II). O tipo de organização e nível de educação parecem ser os melhores preditores da criatividade e da capacidade de inovação, respectivamente. No futuro, pretende-se realizar uma caracterização detalhada das variáveis envolvidas no clima organizacional, pois elas podem explicar, em certa medida, os níveis mais baixos de criatividade dos funcionários públicos.

Palavras-chave: criatividade, inovação, organizações 


\section{Introduction}

Creativity and innovation in the working place are increasingly important factors for organizational performance, success, and long-term survival. Organizations should have a strong interest to harness the ideas and suggestions of their employees, being a good process of idea generation and implementation a strong competitive advantage (Anderson, De Dreu, \& Nijstad, 2004).

If the great scientific, technological, artistic, and philosophical revolutions always earned the status of Big creativity (Big-C), for the last six decades we have witnessed greater appreciation for Little creativity (Little-c), the everyday creativity of ordinary people (Stein, 1987). Furthermore, a correlation between Little and Big creativity has been widely recognized by Torrance's longitudinal studies (Torrance, 1988) and the review studies of the predictive validity of divergent thinking tests (Harrington, Block, \& Block, 1983). Several creativity programs have emerged aiming to promote creative ways of thinking both in scholar and organizational contexts (Sohn \& Jung, 2010).

The distinction between Big-C and Little-c allows us to classify creativity research. Big-C research has a focus on eminent creativity, aiming to learn about creative geniuses and discuss which creative works may last forever (Simonton, 1994; Stein, 1987). Little-c research focuses upon the everyday creativity that shows through mundane activities in which the average person may frequently undertake (Richards, 1990).

However, Kaufman and Beghetto (2009) propose the Four C's of Creativity Model comprising two additional categories: the Mini-c creativity, that highlights the personal and developmental aspects of creativity; and the Pro-c creativity, that represents the developmental and effortful progression beyond Little-c, generally considered a professional-level expertise. This model reflects the authors' belief that almost all aspects of 
creativity (Mini-c; Little-c and Pro-c) may be experienced by every individual. Only the most advanced level, the Big-C, is the prerogative of few.

Only recently have organizations started valuing creativity and innovation, and their full potential is still far from being reached. Instead, "Creativity gets killed much more often than it gets supported. For the most part, this isn't because managers have a vendetta against creativity. On the contrary, most believe in the value of new and useful ideas. However, creativity is undermined unintentionally every day in work environments that were established-for entirely good reasons-to maximize business imperatives such as coordination, productivity, and control." (Amabile, 1998, p. 77). Nowadays, many companies seriously try to promote innovation due to their belief in the importance of individual and organizational creativity (Sohn \& Jung, 2010).

The boundaries between creativity and innovation are not always clear. Some authors support a stronger conceptual differentiation between creativity and innovation (e.g., Rank, Pace, \& Frese, 2004). Others argue that creativity occurs not only in the early stages of innovation processes, suggesting it is rather a cyclical and recursive process of idea generation and implementation (e.g., Paulus, 2002). If creativity is the ability to develop original ideas, discover new solutions and promote scientific inventions, innovation is the complementary ability of implementing those ideas and solutions without which the organizations lose their competitive advantage (Amabile, 1996; Shalley \& Zhou, 2008).

Creativity is usually considered as mostly consisting of intra-individual cognitive processes, and innovation as being mainly an inter-individual social process in the working place (Rank et al., 2004). According to Anderson, Potočnik and Zhou (2014), creativity and innovation are the processes, results and outcomes of attempts to develop new and better ways of doing things. Creativity is related to the idea generation and innovation refers to the 
subsequent stage of idea implementation to improve procedures, practices or products.

According to Amabile (1998), organizational creativity must contemplate divergent ways of thinking, expertise, and high motivational levels. Divergent thinking often refers to flexibility and originality; expertise to intellectual and practical knowledge; and motivation, especially intrinsic motivation, to a genuine and sustained passion to deal with problems despite the effort involved. Organization managers can influence organizational creativity with challenges, freedom, resources, work-group features, supervisory encouragement and organizational support, being able to have a great impact upon motivation and, to a lesser extent, upon divergent thinking and expertise (Amabile, 1998; Amabile, Hadley, \& Kramer, 2002).

Considering the weight of several organizational variables on creativity, Isaksen and Ekvall (2007) identified nine key dimensions of the climate for creativity and innovation: Challenge/Involvement, Freedom, Trust/Openness, Idea-Time, Playfulness/Humour, Conflict, Idea-Support, Debate, and Risk-Taking. West and Richter (2008) mention four aspects of the organizational climate that facilitate innovation: Vision, Participative Safety, Task Orientation, and Support for Innovation. In general, research suggests that an adequate innovation climate increases organizational innovation levels (Jung, Wu, \& Chow, 2008).

From a broader perspective, cultural contexts change with time and geography and are influenced by societies' dominant ideologies, having a great impact upon educational systems and organizational climate (Morris \& Leung, 2010; Zhou \& Su, 2010). The Zeitgeist, far from being a universal influence, must be seen as a contextual one and, in that sense, we should talk about different zeitgeists depending on different cultures, era and geographic locations (Simonton, 2004). 
Several authors have pointed out the importance of research on cultural differences and creativity, especially regarding the similarities and differences between the West and the East (Anderson et al., 2004). Anderson et al. (2014) mention several studies focused upon cultural differences in individual creativity, namely observing the individualism/collectivism cultural values and their influence on leaders, co-workers and the individual process of creativity. Zhou (2006) suggests a paternalistic organizational control model based on a research attending cultural differences and their impact upon team creativity.

Considering the debate about which variables promote creativity and innovation within organisations, it is acknowledged that new ideas, methods and products are fundamental for the organizations' sustainability and competitiveness. Despite considerable research, there seems to be a gap between the organizational interest about creativity management and the actual investment in creativity promotion programs (Sohn \& Jung, 2010). Therefore, industries and organizations could benefit from investing on the development of creativity, innovativeness and propensity for innovation.

Being aware of the importance of creativity and innovation on the organizations' survival, and of the lack of actions meeting the existent needs, a first step must be taken towards making a preliminary diagnosis. In this sense, the objective of the present study is to analyse the impact of gender, age, education level and organization type (private- versus public-sector), on creativity and innovativeness of a convenience sample of Portuguese workers.

Several studies on the influence of gender on creativity have shown no significant differences between men and women (Abraham, Thybuch, Pieritz, \& Hermann, 2014; Ibérico Nogueira \& Almeida, 2010a; Runco, 2007; Urban \& Jellen, 1996). According to some authors (e.g. Ibérico Nogueira \& Almeida, 2010a), the age variable does not seem to have a 
linear effect on the creativity levels of adults. The differences found between individuals of different ages can be better explained by the effect of the education level variable. Thus, individuals with higher education levels tend to be those with higher levels of creativity.

Some authors have also studied the differences between public and private-sector organizations. Angelo, Sanvicente, and Tanabe (1992) analysed 140 public and private Brazilian organizations and concluded that private companies were more profitable than public ones. Rainey and Chun (2005) reviewed literature on the comparative performance of public and private management. Despite contradictory results and the difficulty of taking into account the specific conditions of each type of organization, most authors find that privatesector management usually performs better. According to the authors, this difference might be explained by flawed rewards' systems not based on individual performance criteria. Innovativeness also seems lower in public organizations, possibly due to complex rule systems without incentives for innovation that protect employees from discharge. Furthermore, higher levels of risk aversion in public organizations seem to be linked with red tape, weak links between performance and promotions, and high dependence on elected officials.

\section{Method}

\section{Participants}

The sample consists of 611 participants: 326 males (53.4\%) and 285 females (46.6\%), age ranging from 18 to 64 years $(M=37.23 ; S D=10.32)$. Participants were divided two age groups: Group 1, 18 to 24 years participants $(\mathrm{N}=149)$, and Group 2, more than 25 years participants $(\mathrm{N}=462)$, respectively $24.4 \%$ and $75.6 \%$. Subjects were divided into three groups according to their education level: 135 participants $(22.1 \%)$ in Group $1\left(1^{\circ}-9^{\circ}\right.$ years of education-elementary); $263(43 \%)$ in Group $2\left(10^{\circ}-12^{\circ}\right.$ - high school) and $213(34.9 \%)$ in 
Group 3 (university level). Considering the organizational setting, 411 participants (67.3\%) work in public organizations and 200 in private ones $(32.7 \%)$.

As shown in Table 1, there is information about the prevalence of each gender, age and education level group in public and private organizations. The chi-square test reveals that the education level of participants seems to be associated to the organization type, $\chi^{2}(2,611)$ $=22.63, p=.000$, Cramer's $\mathrm{V}=.192$. The adjusted standardized residuals reveal that the university level is prevalent in private organizations and the high school level is prevalent in public organizations.

Table 1. Prevalence of gender, age and education level in public and private organizations

\begin{tabular}{|c|c|c|c|c|c|c|c|}
\hline \multicolumn{2}{|c|}{ Characteristics } & \multicolumn{4}{|c|}{ Organization type } & \multirow[b]{3}{*}{$\chi^{2}$} & \multirow[b]{3}{*}{$\mathrm{p}$} \\
\hline & & \multicolumn{2}{|c|}{ Public } & \multicolumn{2}{|c|}{ Private } & & \\
\hline & & $\mathrm{n}$ & $\%$ & $\mathrm{n}$ & $\%$ & & \\
\hline \multirow[t]{2}{*}{ Gender } & Male & 230 & $56.0 \%$ & 96 & $48.0 \%$ & & \\
\hline & Female & 181 & $44.0 \%$ & 104 & $52.0 \%$ & 3.43 & .064 \\
\hline \multirow[t]{2}{*}{ Age (years) } & $18-24$ & 103 & $25.1 \%$ & 46 & $23.0 \%$ & & \\
\hline & $25-64$ & 308 & $74.9 \%$ & 154 & $77.0 \%$ & .31 & .648 \\
\hline \multirow[t]{3}{*}{ Education level } & Elementary & 99 & $24.1 \%$ & 36 & $18.0 \%$ & & \\
\hline & High school & 195 & $47.4 \%$ & 68 & $34.0 \%$ & & \\
\hline & University & 117 & $28.5 \%$ & 96 & $48.0 \%$ & 22.63 & .000 \\
\hline
\end{tabular}

Note: Elementary $=1^{\text {st }}-9^{\text {th }}$ year of school; High school $=10^{\text {th }}-12^{\text {th }}$ year of school.

\section{Instruments}

TCT-DP-Test for Creative Thinking and Drawing Production

The TCT-DP (Test for Creative Thinking - Drawing Production; Urban \& Jellen, 
1986), adapted to Portugal by Almeida \& Ibérico Nogueira (2006), it is a figurative test based on the componential model of creativity, built upon six interactive components, three of them of cognitive type: divergent thinking and acting, general knowledge and thinking base, specific knowledge base and area specific skills; and three of them of personality type: focusing and task commitment, motivation and motives, and openness and tolerance of ambiguity. The exploratory factorial analyses of the most recent Portuguese studies found five factors that explain $54,78 \%$ or $60,58 \%$ of total variance, with a sample of 2015 Portuguese workers and a sample of 600 university students, respectively (Ibérico Nogueira \& Almeida, 2010c and Ibérico Nogueira \& Almeida, 2010a). With Portuguese workers, were found adequate levels of internal consistency, with Cronbach's Alpha of .85 and .75 (Almeida \& Ibérico Nogueira, 2009; Ibérico Nogueira \& Almeida, 2010b), which attest to the good psychometric qualities for TCT-DP.

II - Innovativeness Inventory (Hurt, Joseph, \& Cook, 1977). This inventory is based on the assumption of innovativeness as a personality construct that is normally distributed and may be interpreted as the willingness to accept change. This instrument, a likert-type scale (seven-choice answer: strongly agree $=7$, agree $=6$, moderately agree $=5$, undecided $=4$, moderately disagree $=3$, disagree $=2$, strongly disagree $=1$ ), has 20 items and allows the distinction of five innovativeness categories (innovators, early adopters, early majority, late majority and laggards), that distinguish the degree of each person to be adventuresome, to seek and adopt new information and ideas, not depending upon others subjective opinion. The Innovativeness Inventory seems to present good levels of reliability and factorial validity (Almeida, Ibérico Nogueira, \& Silva, 2009). 


\section{Procedure}

Initially, the directors of five private-sector companies and two public-sector companies were contacted and informed about the objectives of this study. With their approval, the objectives were explained to all the potential participants and the conditions of anonymity and confidentiality were also assured. The II was administered after the TCT-DP and, at the final, the participants were asked to fulfil a brief a socio-demographic questionnaire aiming to characterize their gender, age, education level and organization type (private- versus public-sector).

\section{Results}

Table 2 shows the minimum, maximum, mean and standard deviations for scores of the TCT-DP and the II, considering the different gender, age, education level and organization type.

Table 2. Descriptive statistics for TCT-DP and II based on gender, age, education level and organization type

\section{TCT-DP}

II

\begin{tabular}{|c|c|c|c|c|c|c|c|c|c|c|}
\hline \multicolumn{2}{|c|}{ Characteristics } & $\mathrm{n}$ & \multirow{2}{*}{$\begin{array}{c}\text { Min. } \\
3\end{array}$} & \multirow{2}{*}{$\begin{array}{c}\text { Max. } \\
57\end{array}$} & \multirow{2}{*}{$\begin{array}{c}\mathrm{M} \\
17.52\end{array}$} & \multirow{2}{*}{$\begin{array}{l}\text { SD } \\
10.05\end{array}$} & \multirow{2}{*}{$\begin{array}{r}\text { Min. } \\
34\end{array}$} & \multirow{2}{*}{$\begin{array}{c}\text { Max. } \\
89\end{array}$} & \multirow{2}{*}{$\begin{array}{c}\mathrm{M} \\
69.14\end{array}$} & \multirow{2}{*}{$\begin{array}{l}\text { SD } \\
8.58\end{array}$} \\
\hline Gender & Male & 326 & & & & & & & & \\
\hline & Female & 285 & 3 & 39 & 15.60 & 7.90 & 48 & 86 & 68.20 & 7.80 \\
\hline \multirow[t]{2}{*}{ Age (years) } & $18-24$ & 149 & 3 & 54 & 16.28 & 8.51 & 41 & 89 & 68.17 & 7.59 \\
\hline & $25-64$ & 462 & 3 & 57 & 16.73 & 9.36 & 34 & 89 & 68.87 & 7.72 \\
\hline \multirow[t]{2}{*}{ Education level } & Elementary & 135 & 3 & 32 & 13.74 & 6.63 & 48 & 86 & 65.95 & 6.73 \\
\hline & High school & 263 & 3 & 57 & 16.71 & 9.52 & 34 & 89 & 68.39 & 8.08 \\
\hline
\end{tabular}




$\begin{array}{cccccccccccc} & \text { University } & 213 & 3 & 54 & 18.34 & 9.65 & 49 & 89 & 70.83 & 7.17 \\ \text { Organization type } & \text { Public } & 411 & 3 & 57 & 14.70 & 8.38 & 34 & 89 & 68.62 & 7.73 \\ & & \text { Private } & 200 & 7 & 50 & 20.57 & 9.44 & 49 & 86 & 68.88 & 7.63\end{array}$

Note: Elementary $=1^{\text {st }}-9^{\text {th }}$ year of school; High school $=10^{\text {th }}-12^{\text {th }}$ year of school.

A multiple regression was used to assess the ability of four variables (gender, age, education level and organization type) to predict levels of creativity. Preliminary analyses were conducted to ensure no violation of the assumptions of normality, linearity, multicollinearity and homoscedasticity. The total variance explained by the model was $13.2 \%, F(4,606)=23.075, p<.001$. In the final model, three measures were statistical significant, with the organization type recording a higher beta value $(\beta=.286, p<.001)$ than education level $(\beta=.167, p<.001)$ and gender $(\beta=.150, p<.001)$. The organization type explains $8 \%$ of creativity variance and the academic level and gender variables explain $2 \%$ each.

Considering the gender variable, there is a statistical significant difference in scores being males $(M=17.52 ; S D=10.05)$ more creative than females $(M=15.70 ; S D=7.90)$. However, the magnitude of the differences in the means (mean difference $=1.919 \% \mathrm{CI}$ : 3.347 to -.49 ) was very small (eta squared $=.001)$.

Considering the participant's education level, three groups were defined. The Posthoc comparisons using Tam-hane's test indicated that the mean score for high school group $(M=16.71, S D=9.52)$ and university group $(M=18.34, S D=9.65)$ was significantly higher than elementary group $(M=13.74 ; S D=6.63)$. High school group did not differ significantly from university group. Despite reaching statistical significance, the actual difference in mean scores between the groups was quite small. The effect size, calculated using eta squared was 0.03 . 
Considering the organization type, the private workers seem to evidence higher creativity levels $(M=20.57 ; S D=9.44)$ than public ones $(M=14.70 ; S D=8.38)$. The magnitude of differences in the means (mean difference $=5.87 \% \mathrm{CI}:-7.415$ to -4.328 ) was large (eta squared $=.08)$.

A multiple regression was used to assess the ability of the same variables to predict innovativeness levels. To ensure no violation of the assumptions of normality, linearity, multicollinearity and homoscedasticity, the preliminary analyses were performed. The total variance explained by the model was $7.2 \%, F(4,606)=11.69, p<.001$. In the final model, only two measures were statistical significant, with education level $(\beta=.27, p<.001)$ recording a higher beta value than gender $(\beta=.10, p=.017)$. The education level explains $9 \%$ of innovativeness variance and gender explains $6.7 \%$ of innovativeness variance.

In what concerns the impact of education levels on innovativeness, the Post-hoc comparisons using the Tukey test indicated $(p<.05)$ high school group $(M=68.39 ; S D=$ $8.080)$ and university group $(M=70.83 ; S D=7.691)$ with higher innovativeness levels than elementary group $(M=65.95 ; S D=6.726)$, and university group with higher innovativeness than high school group. In terms of perceived innovativeness levels, it was not found a statistical significant difference in scores for men $(M=69.14 ; S D=7.58)$ and women $(M=$ $68.20 ; S D=7.80)$. Considering the impact of the type of organization on innovativeness variable, there is no statistical significant difference in scores for private $(M=68.88 ; S D=$ $7.625)$ and public $(M=68.62 ; S D=7.730)$ sectors.

\section{Discussion}

Concerning the gender variable, males showed higher creativity levels than females, but the small effect size raises concerns about these results. In several studies (Abraham, Thybuch, Pieritz, \& Hermann, 2014; Runco, 2007; Urban, 2004), men and women do not 
show differences in creativity levels. However, He and Wong (2011) used the TCT-DP and, despite not having found differences in creativity between boys and girls, still found significant differences in their variability patterns, suggesting that both genders have strengths and weaknesses in creative thinking, with girls outperforming boys in thoroughness of thinking and boys outperforming girls in boundary-breaking thinking.

Baer and Kauffman (2008) considered several divergent thinking measures with adult samples assessed by many authors, having found contradictory results and showing it is essential to consider the importance of environmental variables for the creativity tests performance beyond the individual ones, such as expertise, knowledge, motivation and genetics.

Other researchers mainly focus on the highest levels of creative achievement, closer to Pro and Big C, where the differences between men and women are the object of different theoretical explanations. Some discuss the importance of the possible link between testosterone and creativity (Reuter et al., 2005) and between neurotransmitters, enzymes and creativity (Eysenk, 1993), although this kind of studies is still at an early stage. Vernon (1989) believes in the importance of genetic factors, without which it would be difficult to understand how highly talented women (e.g. creative writers and dancers) and men (e.g. creative composers and painters) seem to emerge in different fields. Contrastingly, some authors emphasize the differences between men and women in socialization practices, impacts of marriage, or active sex discrimination in the access to resources (Baer \& Kaufman, 2008; Runco, Cramond, \& Pagnani, 2010).

In terms of perceived innovativeness levels, this study did not find any differences between males and females, similarly to the study of Almeida and Ibérico Nogueira (2008b). It should be mentioned that a likert-scale instrument such as II, aiming to evaluate the 
perceptions of individuals, is much likelier to be answered in a similar way by men and women than a figurative creative test such as the TCT-DP.

Considering the age variable, this study did not find differences either in creativity levels or in innovativeness levels between the considered age groups. The studies referred by the authors of TCT-DP (Urban \& Jellen, 1996) did not find differences in creativity levels above 11 years old. However, other authors (Eccles et al., 1993) defend a more complex path for creativity development, having found lower creativity levels among 13-15 year-old subjects, possibly showing higher age-mate influence and sometimes lower self-esteem levels. Given that all participants of the present study were already in their adulthood, the developmental issue may not be very relevant. Moreover, this study only focused on evaluating the creative performance assessed by a figurative test, and not on big accomplishments.

Regarding education levels, the groups with higher levels of education evidenced higher creativity and perceived innovativeness levels, though the detected small effect size for creativity should lead to caution when reading these results. Urban and Jellen (1996) did not find creativity differences between subjects with different education levels. However, other studies (Almeida \& Ibérico Nogueira, 2008b; Ibérico Nogueira \& Almeida, 2010b) suggest that the subjects' education level might be the best predictor for creativity. Academic education can be considered an element of expertise, since it comprises intellectual and practical knowledge (Amabile, 1998).

Testing the adequacy of gender, age, academic level and organization type to predict creativity levels, the present study found better predictive effects for organization type over academic level and gender. Private-sector workers seem to evidence higher creativity levels than their public-sector counterparts. Considering the academic level and gender variables, 
the magnitude of the differences was very small. Previous Portuguese research also found higher creativity levels for private workers than public ones (e.g. Almeida \& Ibérico Nogueira, 2009).

The present study did not characterize organization-specific variables, namely professions and work types, number of working years or the organizational climate, which can have a significant impact upon creativity and innovativeness. It was only possible to observe the difference between private and public-sector organizations in what concerns creativity and innovativeness of their workers, in line with what was expectable after the studies by Angelo et al. (1992) and Rainey and Chun (2005).

There was an association between education level and organization type, being the private-sector workers particularly associated to higher education levels than the publicsector ones. Higher levels of expertise may explain some of the previous results. Moreover, it is plausible to assume that the private organizations' leaders also have higher education levels, which according to Mostafa (2005) can generate a higher predisposition for being creative and innovative.

Given that private and public organizations show differences in creativity but not in innovativeness levels, it is important to reflect upon the used instruments. The TCT-DP requires a figurative expression as a way of measuring creativity, being a relatively culturefree test. Contrastingly, the II is a likert-scale form paper-pencil test that relies on sociocultural variables and can suffer from the social desirability issue. Furthermore, only the academic level variable predicted a small variance of innovativeness, which again may suggest the importance of social desirability and the ability to value it.

It is also important to reflect about the innovativeness concept, as there is a significant gap between the willingness to implement creative ideas and the possibility to do so. Despite 
many people having creative ideas, the cultural or organizational context and climate may deter them from action.

In future studies, the impact of specific organizational variables associated to different management practices upon creativity and innovativeness shall be considered, as suggested by Isaksen and Ekvall (2007). Also, it will be important to reflect upon the instruments, their shortcomings and possible alternatives, as their nature will be more complex when the process of sample characterization becomes more sophisticated by taking into account specific professions and their requirements.

Creativity depends on the non-conformist attitude that may be adapted to the most diverse contexts of life, and it is vital for society to signal, identify, characterise, nurture and stimulate it in school and in the organization and family contexts. As Guilford (1950) suggested, only by investing in creativity will we be able to better characterise and truly promote it with a realistic expectation of a permanent and inevitable change of society in return.

\section{References}

Abraham, A., Thybuch, K., Pieritz, K., \& Hermann, C. (2014). Gender differences in creative thinking: behavioral and fMRI findings. Brain Imaging and Behavior, 8, 39-51. doi:10.1007/s11682-013-9241-4

Almeida, L., \& Ibérico Nogueira, S. (2006). Test of Creative Thinking-Drawing production (TCT-DP): Estudo preliminar na população portuguesa. Poster session presented at XI Conferencia Internacional: Avaliação Psicológica. Formas e Contextos, Universidade do Minho, Braga.

Almeida, L., \& Ibérico Nogueira, S. (2008a). Propensão para Inovar e Criatividade. Paper presented at XV Congresso Internacional INFAD. Psicologia e Relações Interpessoais 
no Ciclo de Vida, Universidade de Évora, Portugal.

Almeida, L., \& Ibérico Nogueira, S. (2008b). Predicting Human Creativity: an Exploratoy Study of the Portuguese Adult Sample. Poster session presented at the $2^{\text {nd }}$ International Conference on Community Psychology, Fundação Calouste Gulbenkian, Portugal.

Almeida; L., \& Ibérico Nogueira, S. (2009). Psychometric Evaluation of Creativity: Portuguese Studies. Poster session presented at 11th European Conference on Creativity and Innovations. Brussels, Belgium.

Almeida, L., Ibérico Nogueira, S., \& Silva, J. (2009). Propensão para inovar e criatividade. Um estudo com adultos trabalhadores portugueses. Revista de Psicologia da Vector Editora, 9 (2), 183-196.

Amabile, T. M. (1996). Creativity and innovation in organizations? Harvard Business Review, 5 (Jan), 1-15.

Amabile, T. M. (1998). How to Kill Creativity? Harvard Business Review, SeptemberOctober, 77- 87.

Amabile, T. M., Hadley, C. N., \& Kramer, S. J. (2002). Creativity under the Gun. Harvard Business Review, 80, 52-61.

Anderson, N., De Dreu, C. K. W., \& Nijstad, B. A. (2004). The routinization of innovation research: A constructively critical review of the state-of-the-science. Journal of Organizational Behavior, 25 (2), 147-173.

Anderson, N., Potočnik, K., \& Zhou, J. (2014). Innovation and Creativity in Organizations: A State-of-the-Science Review, Prospective Commentary, and Guiding Framework. Journal of Management, 40 (5), 1297 -1333. doi:10.1177/0149206314527128

Angelo, C. F., Sanvicente, A. Z., \& Tanabe, M. (1992). Desempenho de empresas estatais e empresas privadas no Brasil . Revista de Administração de São Paulo, 27 (3), 3-15. 
Baer, J., \& Kauffman, J. C. (2008). Gender differences in creativity. Journal of Creative Behavior, 42 (2), 75-105. doi:10.1002/j.2162-6057.2008.tb01289.x

Eccles, J. S.; Midglay, C., Wigfiels, A., Buchanan, M., Reuman, D., Flanagan, C., \& Iver, D. (1993). Development during adolescence. Stage-environment fit on young adolescents. Experiences in schools and families. American Psychologist, 48 (2), 90-101. doi:10.1037/0003-066X.48.2.90

Guilford, J. P. (1950). Creativity. American Psychologist, 5, 444-454. doi:org/10.1037/h0063487

Harrington, D. M., Block, J., \& Block, J. H. (1983). Predicting creativity in preadolescence from divergent thinking in early childhood. Journal of Personality and Social Psychology, 45 (3), 609-623. doi:10.1037/0022-3514.45.3.609

He, W., \& Wong, W. (2011). Gender differences in creative thinking revisited: Findings from analysis of variability. Personality and Individual Differences, 51, 807-811. doi:10.1016/j.paid.2011.06.027

Ibérico Nogueira, S., \& Almeida, L., (2009, July). Mental Disorders: More, Less or Different Creativity. Poster session presented at 11th European Congress of Psychology ECP09, Oslo, Norway.

Ibérico Nogueira, S., \& Almeida, L. (2010). Psychometric Studies with TCT- DP. Paper presented at 27th International Congress of Applied Psychology, Melbourne, Australia. Ibérico Nogueira, S., \& Almeida, L. (2010b). Caracterização dos níveis de criatividade em adultos portugueses. Paper presented at III Congresso Brasileiro: Psicologia, Ciência e Profissão, São Paulo, Brasil.

Ibérico Nogueira, S., \& Almeida, L. (2010c). TCT-DP (Test for Creative Thinking-Drawing Production): estudos psicométricos na população portuguesa. Poster session presented 
at II Congresso Brasileiro: Psicologia, Ciência e Profissão, São Paulo, Brasil.

Ibérico Nogueira, S., \& Almeida, L. (2012). Criatividade no ensino obrigatório: estudos de validação do TCT-DP (Test for Creative Thinking-Drawing Production) na população portuguesa. Poster session presented at $1^{\circ}$ Congresso Nacional da Ordem dos Psicólogos Portugueses: Afirmar os Psicólogos. Lisboa, Portugal.

Isaksen, S. G., \& Ekvall, G. (2007). Assessing the context for change: A technical manual for the Situational Outlook Questionnaire® - Enhancing performance of organizations, leaders and teams for over 50 years (2nd ed.), Buffalo, NY: The Creative Problem Solving Group, Inc.

Jung, D., Wu, A., \& Chow, C. W. (2008). Towards understanding the direct and indirect effects of CEOs' transformational leadership on firm innovation. The Leadership Quarterly, 19 (5), 582-594. doi:10.1016/j.leaqua.2008.07.007

Kaufman, J. C., \& Beghetto, R. A. (2009). Beyond big and little: The Four C Model of Creativity. Review of General Psychology, 13, 1-12. doi:10.1037/a0013688

Morris, M. W., \& Leung, L. (2010). Creativity East and West: Perspectives and parallels. Management and Organization Review, 6 (3), 313-327. doi:10.1111/j.17408784.2010.00193.x

Mostafa, M. (2005). Factors affecting organisational creativity and innovativeness in Egyptian business organisations: an empirical investigation. The Journal of Management Development, 24, 7- 33. doi:org/10.1108/02621710510572326.

Paulus, P. B. (2002). Different ponds for different fish: A contrasting perspective on team innovation. Applied Psychology: An International Review, 51 (3), 394-399. doi:10.1111/1464-0597.00973

Rainey, H. G., \& Chun, Y. H. (2005). Public and Private Management Compared. in E.Ferlie, 
L. E. Lynn, \& C. Pollitt (Eds). The Oxford Handbook of Public Management (pp.72102). Oxford: Oxford University Press.

Rank, J., Pace, V. L., \& Frese, M. (2004). Three avenues for future research on creativity, innovation, and initiative. Applied Psychology: An International Review, 53 (4), 518528. doi:10.1111/j.1464-0597.2004.00185.x

Reuter, M., Panksepp, J., Schnabel, N., Kellerhoff, N., Kempel, P., \& Hennig, J. (2005). Personality and biological markers of creativity. European Journal of Personality, 19, 83-95. doi:10.1002/per.534.

Richards, R. (1990). Everyday creativity, eminent creativity, and health: "Afterview” for CRJ issues on creativity and health. Creativity Research Journal, 3 (4), 300-326. doi:org/10.1080/10400419009534363

Runco, M. A. (2007). Creativity. Theories and themes: research, development, and practice. Amsterdam, New York: Elsevier Academic Press.

Runco, M. A., Cramond, B., \& Pagnani, A. R. (2010). Gender and creativity. In J. C. Chrisler \& D. R. McCreary (Eds.), Handbook of gender research in psychology (pp. 343-357). New York: Springer.

Shalley, C. E., \& Zhou, J. (2008). Organizational creativity research: A historical overview. In J. Zhou \& C. E. Shalley (Eds.), Handbook of organizational creativity (pp. 3-31). Hillsdale, NJ: Erlbaum.

Simonton, D. K. (1994). Greatness: Who makes history and why. New York: Guilford Press.

Simonton, D. K. (2004). Creativity in science: Chance, Logic, Genius and Zeitgeist. UK: Cambridge University Press.

Sohn, S. Y., \& Jung, C. S. (2010). Effect of creativity on Innovation: do creativity initiatives have significant impact on innovative performance in Korean firms? Creativity Research 
Journal, 22 (3), 320-328. doi:org/10.1080/10400419.2010.503542

Stein, M. I. (1987). Creativity research at the crossroads: A 1985 perspective. In S. G. Isaksen (Ed.), Frontiers of creativity research: Beyond the basics (pp. 417-427). New York: Plenum Press.

Torrance, E. P. (1988). The nature of creativity as manifest in its testing. In R. J. Sternberg (Ed.), The nature of creativity: contemporary psychological perspectives (pp. 43-75). NY: Cambridge University Press.

Urban, K. K. (2004). Assessing creativity: The test for creative thinking-drawing production (TCT-DP). The concept, application, evaluation, and international studies. Psychology Science, 46 (3), 387-397.

Urban, K. K., \& Jellen, H. G. (1986). Assessing creative potential via drawing production: The Test for Creative Thinking - Drawing Production (TCT-DP). In A. J. Cropley, K. K. Urban, H. Wagner, \& W. Wieczerkowski (Eds.), Giftedness: A continuing worldwide challenge (pp.163-169). New York, NY: Trillium Press.

Urban, K. K., \& Jellen, H. G. (1996). Test for Creative Thinking - Drawing Production (TCTDP). Lisse, Netherlands: Swets \& Zeitlinger.

Vernon, P. A. (1989). The heritability of measures of speed of information processing. Personality and Individual Differences, 10, 573-576.

West, M. A., \& Richter, A. (2008). Climates and cultures for innovation at work. In J. Zhou \& C. E. Shalley (Eds.), Handbook of organizational creativity (pp. 211-236). Hillsdale, NJ: Erlbaum.

Zhou, J. (2006). A model of paternalistic organizational control and group creativity. Research on Managing Groups and Teams, 9, 75-95. doi:10.1016/S15340856(06)09004-9 
Zhou, J., \& Su, Y. (2010). A missing piece of the puzzle: The organizational context in cultural patterns of creativity. Management and Organization Review, 6 (3), 39-413. doi:10.1111/j.1740-8784.2010.00192.x

Recepción: 14 de mayo de 2018

Última Revisión: 17 de junio de 2019

Aceptación Final: 25 de junio de 2019 